\title{
Development and Characterization of Phosphate-Based Glass Coatings via Suspension High-Velocity Oxy-Fuel (SHVOF) Thermal Spray Process
}

\author{
S. Bano ${ }^{1}$ A. Rincon Romero ${ }^{1} \cdot$ Md Towhidul Islam $^{1}$ - D. M. Grant ${ }^{1}$. \\ I. Ahmed ${ }^{1} \cdot$ T. Hussain ${ }^{1}$
}

Submitted: 14 December 2020/in revised form: 1 June 2021 / Accepted: 9 June 2021 / Published online: 21 July 2021 (C) The Author(s) 2021

\begin{abstract}
Phosphate-based glasses (PBGs) are promising materials for biomedical applications due to their biocompatible and fully resorbable characteristics in aqueous environments. These glasses can be coated onto metal substrate via the technique of suspension high-velocity oxy-fuel (SHVOF) thermal spraying to produce nanostructured coatings with improved physical and mechanical properties. PBGs coatings were produced using SHVOF thermal spray process at 50 and $75 \mathrm{~kW}$ flame power. The $75 \mathrm{~kW}$ coating was rougher $\left(R_{\mathrm{a}}=3.6 \pm 0.1 \mu \mathrm{m}\right)$ than the 50 $\mathrm{kW}$ coating $\left(R_{\mathrm{a}}=2.7 \pm 0.1 \mu \mathrm{m}\right)$, whereas the $50 \mathrm{~kW}$ coating was much thicker $(24.6 \pm 2.3 \mu \mathrm{m})$ than the $75 \mathrm{~kW}$ coating $(16.0 \pm 3.4 \mu \mathrm{m})$. Due to the rougher surface, the 75 $\mathrm{kW}$ coating showed high degradation and ion release rates. Moreover, structural changes were observed by Raman analysis, and the initial glass formulation contained $Q^{1}$ (phosphate tetrahedra with one-bridging oxygen) and $\mathrm{Q}^{2}$ (phosphate tetrahedra with two-bridging oxygen) species. However, the coatings showed a reduction of $\mathrm{Q}^{2}$ species and higher concentrations of $\mathrm{Q}^{1}$ and $\mathrm{Q}^{0}$ (phosphate tetrahedra with no-bridging oxygen) species, which led to lower degradation rates and reduced ion release profiles in the glass coating compared to the initial glass.
\end{abstract}

Keywords bioactive glass $\cdot$ biomaterials applications $\cdot \mathrm{P}$ $40 \cdot$ SHVOF

T. Hussain

tanvir.hussain@nottingham.ac.uk

1 Advanced Materials Research Group, Faculty of Engineering, University of Nottingham, Nottingham NG7 2RD, UK

\section{Introduction}

Phosphate-based glasses (PBG) are considered as a thirdgeneration biomaterials, because these are fully resorbable in aqueous environments and these release ions (inorganic phosphate, $\mathrm{Ca}^{2+}, \mathrm{Mg}^{2+}$ and $\mathrm{Na}^{+}$) that are easily assimilated by the human body, which makes these glasses highly suitable for biomedical applications, such as degradable implant materials (Ref 1). In PBGs, $\mathrm{P}_{2} \mathrm{O}_{5}$ is the network former, and the orthophosphate $\left(\mathrm{PO}_{4}{ }^{3-}\right)$ tetrahedron represents the basic unit. These tetrahedrons bond through the bridging oxygen atoms, creating the P-O-P network that forms the glass structure. The number of bridging oxygen atoms linked to the adjacent tetrahedra is represented by $\mathrm{Q}^{\mathrm{n}}$ (where ' $n$ ' is the number of bridging oxygen per tetrahedra), and this parameter is used to describe the structure of PBGs (Ref 2). $\mathrm{Na}_{2} \mathrm{O}$ and $\mathrm{CaO}$ are usually present in PBGs as network modifiers to control their dissolution in aqueous media (Ref 3). Ions such as $\mathrm{Ca}(\operatorname{Ref} 4), \mathrm{F}(\operatorname{Ref} 5)$, and $\mathrm{Sr}$ (Ref 6) were added to increase bone regeneration, and other ions such as $\mathrm{Cu}(\operatorname{Ref} 7)$ and $\mathrm{Ag}(\operatorname{Ref} 8)$ were used to improve the antibacterial properties. In addition, Ti (Ref 9) and $\mathrm{Fe}$ (Ref 10) were incorporated into PBGs to tailor their durability and control their degradation for use in specific end applications (Ref 11, 12).

The dissolution mechanism of PBGs in aqueous environments involves hydration, followed by hydrolysis of the PBGs chains (Ref 13). In the first step, hydration, the glass exchanges $\mathrm{Na}^{+}$ions with $\mathrm{H}^{+}$ions, resulting in a hydrated layer at the interface between the glass surface and media. The second stage involves the hydrolytic attack of the phosphate chains that are released into the solution (Ref 13). Bunker et al. proposed that the hydration is the dominating step in the glass dissolution process and involves two kinetic stages according to the dissolved 
profiles $(q)$ in time $(t)(\operatorname{Ref} 14)$. In the first stage, the dissolution occurs linearly $(q \propto t)$ until the saturation of the network, after which hydration of the glass occurs by diffusion following an exponential $\left(q \propto t^{1 / 2}\right)$ degradation profile (Ref 14, 15). In addition, it was also reported that the degradation rate of PBGs is highly influenced by the $\mathrm{pH}$ of the media, since higher degradation would occur at lower $\mathrm{pH}$ (Ref 13-16).

The degradation of PBGs can easily be tailored and controlled by changing the glass compositions to balance the tissue growth; therefore, they have been proposed for different biomedical applications, using varying geometries such as glass fibers (Ref 16) or porous microspheres (Ref 17, 18). In addition, they could potentially be exploited as coatings on metallic implants to enhance bone tissue growth (Ref 2). Physical vapor deposition has been previously explored to produce thin-film PBGs coatings via radio-frequency magnetron sputtering (Ref 15 ). In the process of sputtering, the solid target is bombarded with ions or neutral particles, resulting in the removal of material from the target via atomization and its deposition onto a substrate to form a thin film. Stuart et al. have studied PBG coatings obtained on Ti6Al4V through magnetron sputtering, obtaining coatings with similar composition to the initial glass; however, the structure of these coatings suffered significant changes establishing that the glass structure of the coatings was highly depolymerized, and the coatings contained a higher percentage of $\mathrm{Q}^{2}$ (having two bridging oxygen) species (up to $45.2 \%$ ) than the starting melt-quenched glass (which had $\mathrm{Q}^{2}$ species up to $31.0 \%$ ) (Ref 15,19$)$. These structural differences between magnetron-sputtered PBG coatings and the initial melt-quenched glass represent a noticeable limitation of this technique.

The coatings had reduced phosphate content than the melt-quenched glass due to the lower sputtering rates of phosphate ions; at the same time, the network-modifying ions such as $\mathrm{Ca}, \mathrm{Na}$, and $\mathrm{Mg}$ deposited at higher rates. It was shown that the order of sputtering was $\mathrm{P}<\mathrm{Fe}<\mathrm{Ca}<$ $\mathrm{Mg}<\mathrm{Na}$ due to the decreasing dissociation energy (Ref $20)$. Also, higher sputtering powers $(>100 \mathrm{~W})$ could cause cracking of the target (Ref 2). Moreover, the thickness of the PBGs coatings produced through radio-frequency magnetron sputtering is only few microns $(2.5,2.7 \mu \mathrm{m})$ (Ref 14,18 ) and the process takes much longer to produce sufficient thickness coatings. For example, some metals were deposited at $1 \mu \mathrm{m} / \mathrm{h}$ or even slower $(50 \mathrm{~nm} / \mathrm{h})$ if RF sputtering was used (Ref 21).

The emerging technique of suspension high-velocity oxy-fuel (SHVOF) thermal spray could represent an alternative to produce PBGs coatings. It has been used to deposit coatings of a wide variety of materials such as ceramics, bioceramics, bioactive glasses, metals and cermets (Ref 22). This technology allows for rapid deposition (usually only a few minutes) of micro- and nanometric particles in suspension form. A modified gas-fuelled high-velocity oxy-fuel (HVOF) torch is employed in SHVOF thermal spraying to process the liquid suspension. As the suspension is axially injected inside of the combustion chamber of the torch, complete mixing of the suspension droplets with the gas takes place. Depositing particles are heated by the gas in the combustion chamber and in the expansion nozzle. Upon expansion to ambient pressure, the gas attains supersonic velocity and projects the solid particles at high velocities toward the target. Extensive flattening of the particles occurs on the substrate resulting in dense microstructure with excellent cohesive and adhesive strength (Ref 23). With SHVOF, thin and thick coatings can be deposited, which can preserve the properties (chemical composition and phase) of the feedstock. The coatings deposited by SHVOF usually exhibit fine microstructure having excellent mechanical properties (Ref 22-25).

This work proposes the production of PBG coatings using SHVOF thermal spray to assess the potential development of resorbable coatings. The aim was to study the effect of the processing parameters (flame power) on the microstructure and chemical composition of the coatings. Moreover, the degradation and the ion release profiles of these coatings in phosphate buffer saline solution (PBS) and Milli-Q water were also investigated to establish how the degradation of the coatings was affected by the surface topography and the glass structure obtained with the different parameters.

\section{Materials and Methods}

\section{Feedstock Material}

A phosphate-based glass with nominal composition of 40 mol.\% $\mathrm{P}_{2} \mathrm{O}_{5}, 16 \mathrm{~mol} . \% \mathrm{CaO}, 24 \mathrm{~mol} . \% \mathrm{MgO}$ and $20 \mathrm{~mol} . \%$ $\mathrm{Na}_{2} \mathrm{O}$, later referred to as P-40 (Ref 11), was prepared using the following precursors: sodium dihydrogen phosphate $\left(\mathrm{NaH}_{2} \mathrm{PO}_{4}\right)$, calcium hydrogen phosphate $\left(\mathrm{CaHPO}_{4}\right)$, magnesium hydrogen phosphate trihydrate $\left(\mathrm{MgHPO}_{4} 3\right.$ $\mathrm{H}_{2} \mathrm{O}$ ), and phosphorous pentoxide $\left(\mathrm{P}_{2} \mathrm{O}_{5}\right)$ (Sigma-Aldrich, UK). Amounts of each precursor were weighed and mixed manually. After mixing these were transferred to a platinum-rhodium crucible (Birmingham Metal Company, Birmingham, UK) and the crucible was then placed in a furnace at $350{ }^{\circ} \mathrm{C}$ for $30 \mathrm{~min}$ to remove moisture. Then, the mixture was melted at the temperature of $1150{ }^{\circ} \mathrm{C}$ for $1.5 \mathrm{~h}$. The molten glass was then quenched at room temperature using a steel slab. The size of the P-40 glass was reduced using a PM-100 ball mill (Retsch1-5, Germany) in 
a zirconia jar with $5 \mathrm{~mm}$ zirconia balls at $450 \mathrm{rpm}$ for 20 min. The resultant powder had $D_{10}=1.5 \mu \mathrm{m}, D_{50}=12 \mu \mathrm{m}$ and $D_{90}=48 \mu \mathrm{m}$ and was again ball-milled with $2 \mathrm{~mm}$ zirconia beads at $350 \mathrm{rpm}$ for $20 \mathrm{~min}$ to reduce the size of the particles further, to allow the preparation of the suspension that will be used in the spray process.

The powder suspension was prepared by adding $10 \mathrm{wt} . \%$ ball-milled P-40 glass powder in 90 wt.\% water. The ballmilled powder was observed by scanning electron microscopy (SEM) (JEOL 6490, Tokyo, Japan) and energy-dispersive X-ray spectroscopy (EDX) (INCA 350, Oxford Instruments, Abingdon, UK). The size distribution of the P-40 glass particles in suspension was measured by laser diffraction method (Beckman Coulter, Inc., California, USA) using a $750 \mathrm{~nm}$ laser.

\section{Suspension Thermal Spray Processing}

304 stainless steel substrates were grit-blasted using F100 brown alumina with a size range of $0.125-0.149 \mathrm{~mm}$. An ultrasonic bath was used to clean the substrates in industrial methylated spirit (IMS) for the removal of any embedded alumina particles. After cleaning, the substrates were mounted onto a carousel rotating at $73 \mathrm{rpm}$ with a vertical axis of rotation. A modified Top Gun HVOF thermal spray torch (GTV gmbH, Germany) with axial injection was used to spray the suspension. The diameter of the suspension injector was $0.3 \mathrm{~mm}$, while the combustion chamber was $22 \mathrm{~mm}$ long with $135 \mathrm{~mm}$ long barrel nozzle. The suspension was fed from a pressurized vessel at a flow rate of $50 \mathrm{ml} / \mathrm{min}$. The nozzle was cleaned after each spray run with deionized water. The torch was mounted onto a traverse unit moving at a speed of $5 \mathrm{~mm} / \mathrm{s}$ at a stand-off distance of $85 \mathrm{~mm}$ to the substrates on the carousel. Twenty traverse gun passes were used to build up the coating. Compressed air jets were used to provide cooling to substrates during and after spray.

P-40 suspension was sprayed by following the parameters given in Table 1, which were selected in order to obtain coatings with an appropriate thickness, porosity and adhesion to the substrate based on the deposition of a typical bioactive glass (45S5) coatings by SHVOF thermal spray investigated in a previous research (Ref 22). Theoretical flame energy (in $\mathrm{kW}$ ) was calculated, and the coatings were labeled according to their theoretical flame power.

\section{Coatings Characterization}

An SEM (Jeol 6049) was used at $20 \mathrm{kV}$ accelerating voltage to examine the surface morphology and cross section of the coatings. For cross section examination, the coatings were cut transversally with a SiC cutting disk using a precision cutting machine (Brilliant 220, ATM $\mathrm{GmbH}$, Mammelzen, Germany). After cutting, the samples were mounted in Bakelite resin and then ground and polished to $1 \mu \mathrm{m}$ surface finish. Before SEM examination, all samples were carbon-coated as these were non-conductive. EDX surface and line scan across the cross section were done using INCA software.

The surface roughness of the coatings was analyzed with a Talysurf Profilometer (Taylor Hobson Ltd., UK) with stylus radius of $2 \mu \mathrm{m}$. The sampling distance was kept 0.5 $\mu \mathrm{m}$ in the scan direction, while the stylus was moving with a speed of $0.25 \mathrm{~mm} / \mathrm{s}$. Porosity and thickness of the coatings were determined by ImageJ software (NIH, USA) with thresholding technique to highlight features of interest with five SEM secondary electron (SE) images from different regions of the cross section.

An x-ray diffractometer (D500, Siemens) with a $\mathrm{Cu} \mathrm{K-} \alpha$ radiation source in Bragg-Brentano $\theta-2 \theta$ configuration was used to determine any phase change in $\mathrm{P}-40$ from powder to coatings. The scan was performed over a $2 \theta$ range of $20^{\circ}-70^{\circ}$ with step of $0.05^{\circ}$ and $7 \mathrm{~s}$ dwell time. Raman analysis was conducted to investigate the structural connectivity of P-40 powder and coatings. A LabRAM HR spectrometer (Horiba-Jobin-Yvon) was used for Raman analysis, with a $532 \mathrm{~nm}$ laser with a $100 \mathrm{X}$ objective, 300 $\mu \mathrm{m}$ pinhole and diffraction grating of 600 lines $/ \mathrm{mm}$. All spectra were acquired for 20 accumulations of 30 seconds each.

\section{Ion Release Profiles}

The ion release profiles of the coatings were determined by immersing $9 \mathrm{~mm}$ disks coatings samples in $15 \mathrm{ml}$ of Milli$\mathrm{Q}$ water at $37{ }^{\circ} \mathrm{C}(\operatorname{Ref} 11,15)$. The samples were kept in the medium for 1, 3, 7 days, and the medium was refreshed at each time point. After each time point, the medium was analyzed for $\mathrm{Ca}, \mathrm{Mg}, \mathrm{Na}, \mathrm{P}$ ions concentration using an Inductively Coupled Plasma Mass Spectrometry (ICP-MS, Thermo-Fisher Scientific iCAP-Q) coupled with a $2 \times 250$ mm Ion- Pac1 CS12A separator column.
Table 1 Process parameters for S-HVIOF spraying of P-40 glass

\begin{tabular}{lccc}
\hline Run number & $\mathrm{H}_{2}$ flow rate, $1 / \mathrm{min}$ & $\mathrm{O}_{2}$ flow rate, $1 / \mathrm{min}$ & Flame power, $\mathrm{kW}$ \\
\hline 1 & 355 & 152 & 50 \\
2 & 527 & 226 & 75 \\
\hline
\end{tabular}




\section{Degradation Study}

P-40 coated discs (diameter around $9 \mathrm{~mm}$ ) were placed in $15 \mathrm{ml}$ phosphate buffer saline solution (PBS) solution (pH $\approx 7.40$ ) and Milli-Q water and incubated at $37^{\circ} \mathrm{C}$. The samples were left in the solution for 1, 3, 7 and 14 days. After each time point, the samples were removed from the suspension, dried in the oven for one hour at $50{ }^{\circ} \mathrm{C}$ to remove surface moistures and the mass loss of the samples was calculated using Equation 1.

$$
\frac{\text { Mass loss }}{\text { Surface area }}=\frac{M_{\mathrm{o}}-M_{\mathrm{t}}}{\text { Surface area } t}
$$

where $M_{\mathrm{o}}$ is the mass of the starting sample and $M_{\mathrm{t}}$ is mass at a particular time ' $t$ ' during the study.

Then, the samples were immersed in PBS solution and Milli-Q water until the next time point. A microprocessor $\mathrm{pH}$ meter (Mettler Toledo, Schwerzenbach, Switzerland) was used for $\mathrm{pH}$ measurement of $\mathrm{PBS}$, and $\mathrm{pH}$ meter was calibrated using standard $\mathrm{pH}$ buffer solutions of $\mathrm{pH} 4.0, \mathrm{pH}$ 7.0, and pH 10.0 (Fisher Scientific, UK).

\section{Results}

\section{Powder Characterization}

The size distribution of the glass particles used for suspension preparation and measured by laser diffraction particle size analyzer is given in Fig. 1(a). The powder had $D_{10}=1.1 \mu \mathrm{m}, D_{50}=3.6 \mu \mathrm{m}, D_{90}=14 \mu \mathrm{m}$, with a wide distribution range from $2 \mu \mathrm{m}$ to $27 \mu \mathrm{m}$. SEM micrograph in Fig. 1(b) also showed the angular morphologies of the particles and confirmed a mixture of fine and coarser particles.

\section{Morphology and Microstructure of the Coatings}

The surface morphology of the P-40 coatings deposited at $50 \mathrm{~kW}$ and $75 \mathrm{~kW}$ is shown in Fig. 2. Both coatings surfaces were covered with large globules that were evenly distributed throughout the surface of the coatings (see Fig. 2a and d). On both coatings, the globules were the same diameter measuring approximately $20 \mu \mathrm{m}$. However, the morphology of the globules observed revealed significant differences depending on the flame power used for the coating deposition. The globules present on the $50 \mathrm{~kW}$ coating (Fig. 2b) revealed the presence of fine particles that provided a rough exterior to the globules. In contrast, the globules present on the $75 \mathrm{~kW}$ coating (Fig. 2e) presented an even skin. In the hump-free areas, the molten splats could clearly be observed in both cases, as can be seen in Fig. 2(c) and (f). The material had clearly melted in both (a)
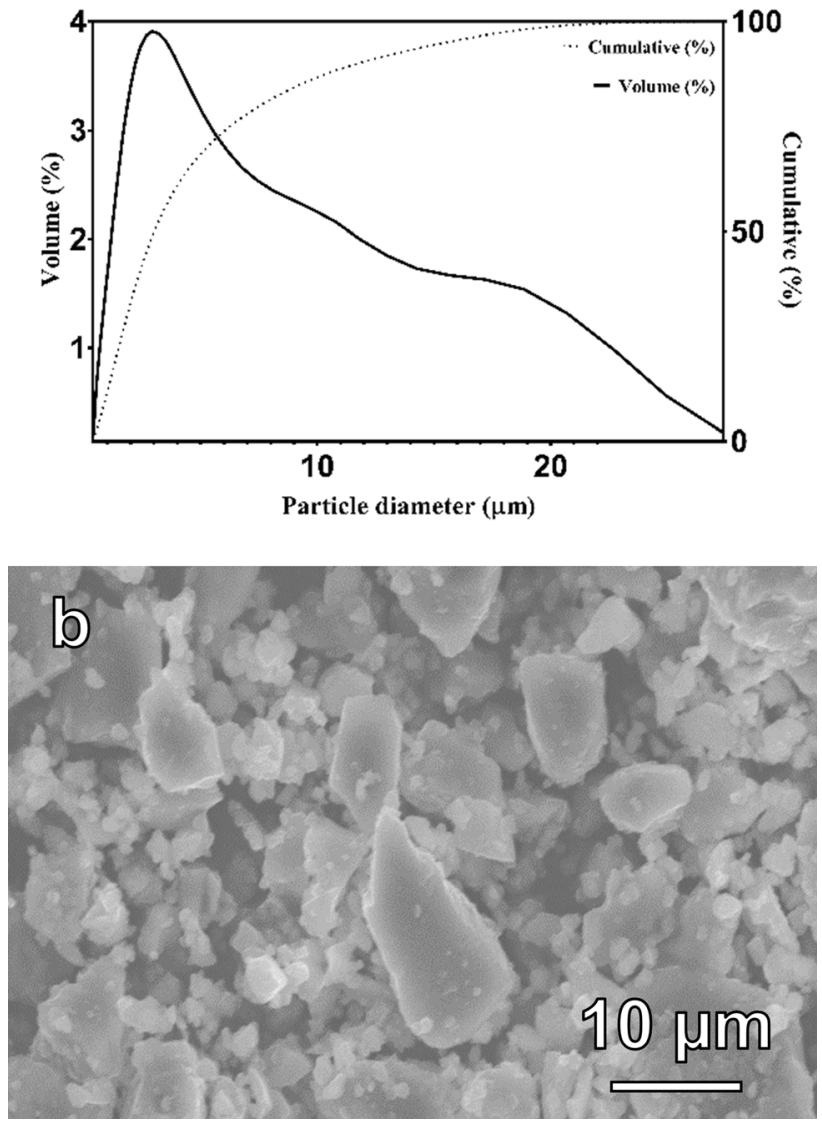

Fig. 1 Particle size distribution (a) and SEM (SE) image (b) of ballmilled P-40 glass

cases so that the size of individual splats could not be estimated as the ends of each splat were joined to other splats. However, the finer partially molten particle can also be seen; these unmolten particles seem more abundant in the $50 \mathrm{~kW}$ than in the coating sprayed at $75 \mathrm{~kW}$.

The cross-sectional images of the P-40 coatings are shown in Fig. 3. As can be seen, both coatings were well adhered, and no delamination was observed at the interface between coating and substrate. However, the thickness of these coatings was not uniform along the cross section. From Fig. 3(a) and (c), it can be seen that the coating deposited at $50 \mathrm{~kW}$ was 1.5 times thicker than the coating deposited $75 \mathrm{~kW}$. However, the $75 \mathrm{~kW}$ coating was less porous $(1.5 \pm 0.4 \%)$ in comparison to the $50 \mathrm{~kW}$ coating, which had a porosity of $2.9 \pm 0.2 \%$ (see Table 2). Both coatings were rough (Table 2), with the $75 \mathrm{~kW}$ coating being comparatively rougher $(3.6 \pm 0.1 \mu \mathrm{m})$ than the 50 $\mathrm{kW}$ coating (at $2.7 \pm 0.1 \mu \mathrm{m}$ ).

To explore any compositional changes in P-40 glass after thermal spray, EDX scans were carried out along the cross section of the coatings and can be seen in Fig. 4, where elemental wt.\% is presented as function of distance 

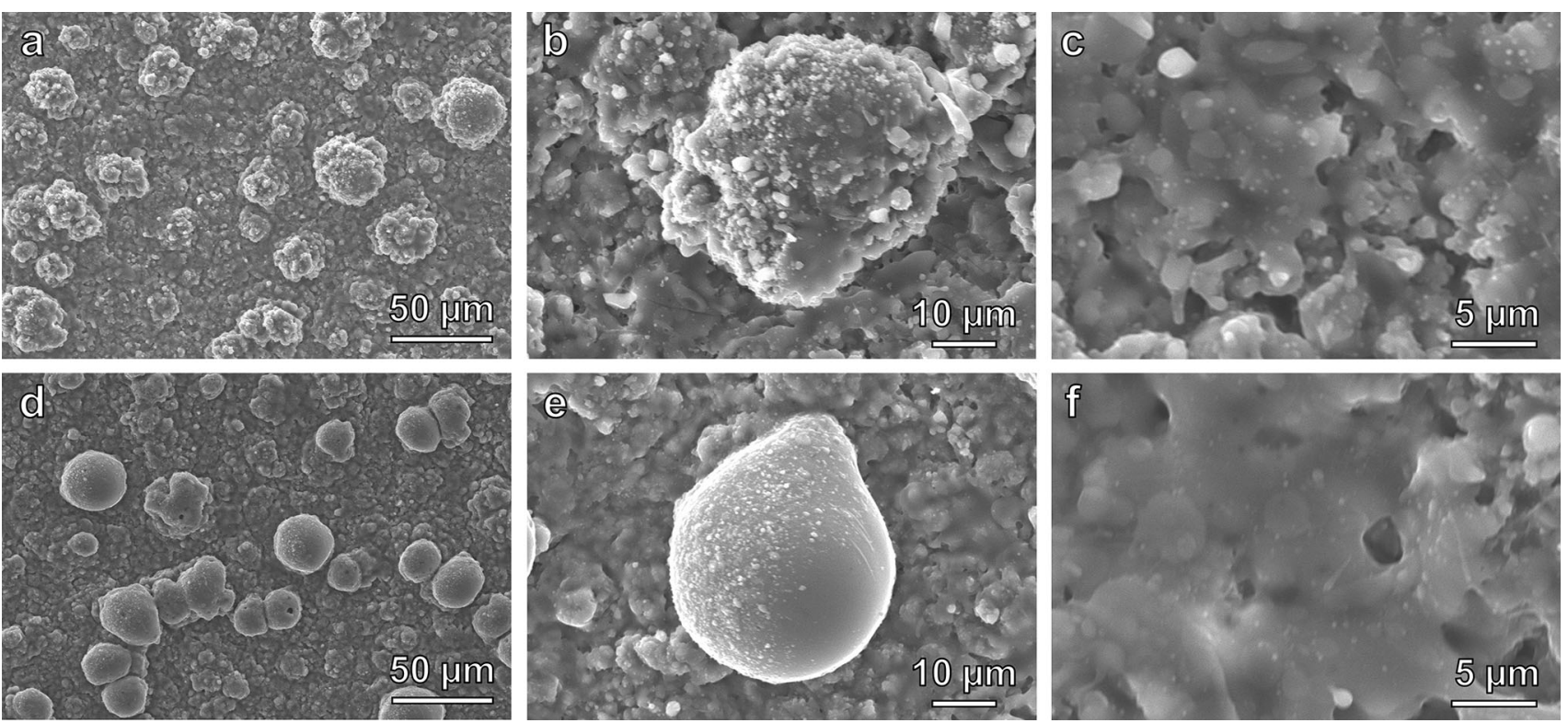

Fig. 2 SEM (SE) images of the surface morphology of P-40 coatings (a), (b) and (c) at $50 \mathrm{~kW}$, and (d), (e) and (f) at $75 \mathrm{~kW}$, at increasing magnification
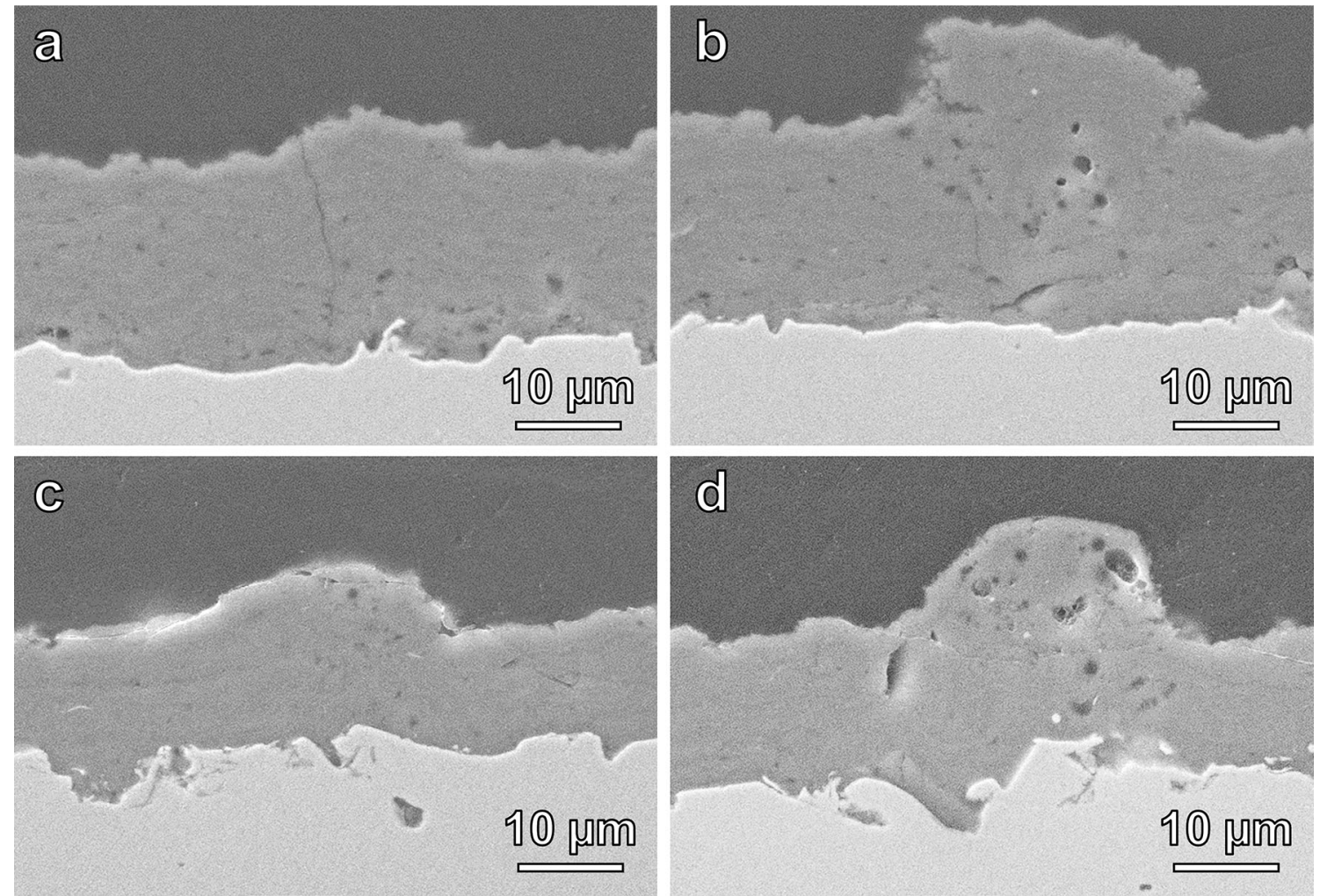

Fig. 3 SEM (SE) images of the cross sections of (a) and (b) for coating deposited at $50 \mathrm{~kW}$, and (c) and (d) for coating deposited at $75 \mathrm{~kW}$ at different globules and globules-free regions of the coatings

from the interface between coating and substrate to the top of the coatings (along with their corresponding BSE images).
In the P-40 coating deposited at $50 \mathrm{~kW}$, the composition was approximately constant along the cross section, while going from the coating-substrate interface to the top of coating. However, slight variation was observed in 
comparison to the starting powder composition (Table 3). The $\mathrm{P}$ content was 26.4 wt.\% (Table 3) in the starting

Table 2 Morphological properties of P-40 glass coatings deposited at 50 and $75 \mathrm{~kW}$ flame power

\begin{tabular}{lccc}
\hline Coating & Thickness, $\mu \mathrm{m}$ & Porosity, $\%$ & Surface roughness $R_{\mathrm{a}}, \mu \mathrm{m}$ \\
\hline R50 & $24.6 \pm 2.3$ & $2.9 \pm 0.2$ & $2.7 \pm 0.1$ \\
R75 & $16.0 \pm 3.4$ & $1.5 \pm 0.4$ & $3.6 \pm 0.1$ \\
\hline
\end{tabular}

powder, which had slightly reduced to $24.5 \mathrm{wt} \%$ at the coating-substrate interface. However, the same starting value at $26.4 \mathrm{wt} \%$ was observed at the top of the coating. Moreover, 12.5 wt.\% $\mathrm{Na}$ was present in the powder before spraying, which had been reduced to approximately 5.5 wt. $\%$ at the coating-substrate interface and remained at this value through all the thickness of the coating. Ca content present in the powder was 6.2 wt.\% and was around 9.2 wt. $\%$ at the interface and did not vary until the top of the coating. Mg wt. $\%$ was increased to $10 \mathrm{wt} . \%$ at the interface
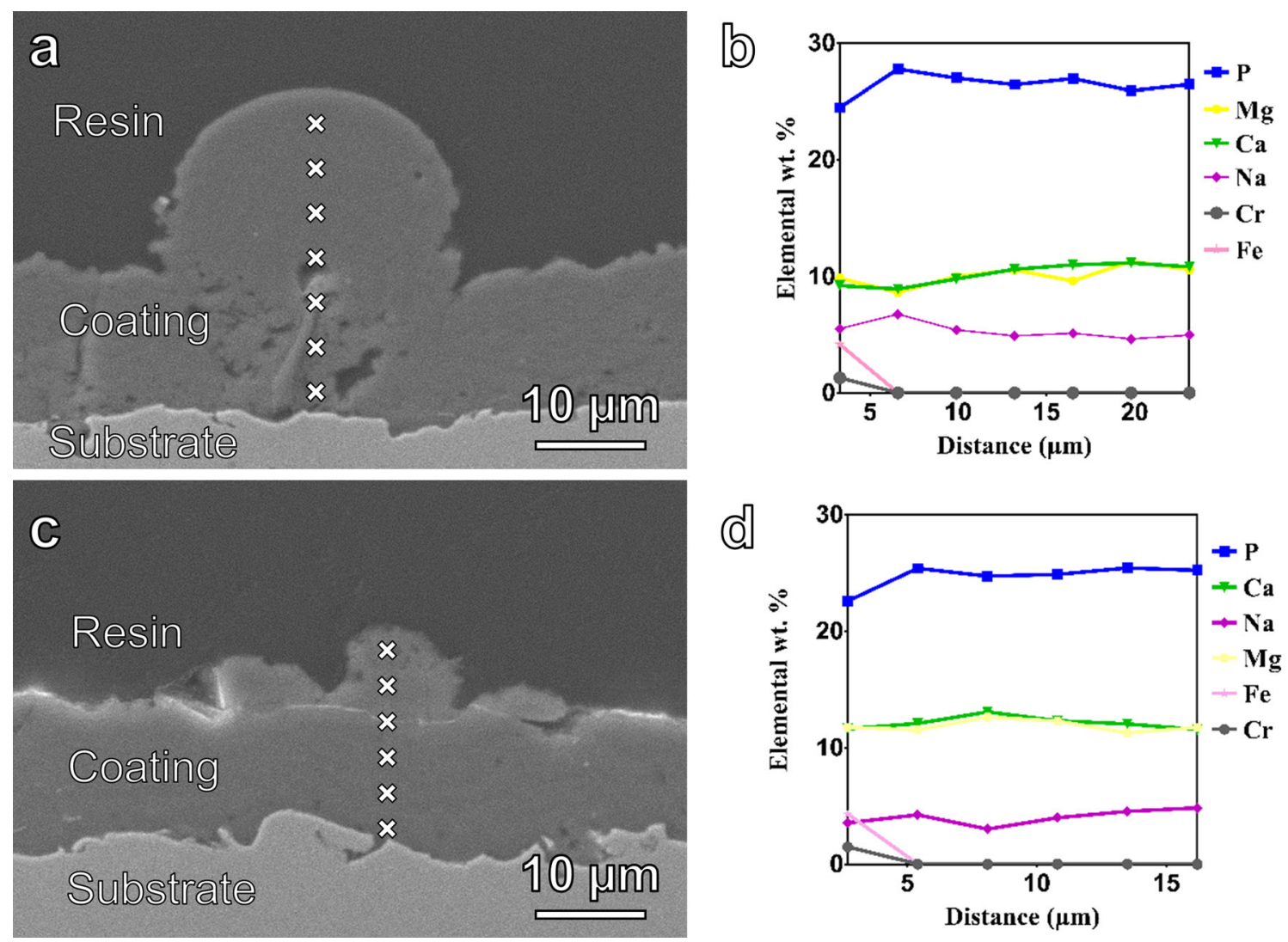

Fig. 4 BSE images for the cross section of P-40 phosphate glass coating deposited (a) at $50 \mathrm{~kW}$ and (c) at $75 \mathrm{~kW}$, (b) and (d) the corresponding EDX line scan along the cross section of the coatings starting at the interface between coating and substrate to the top of the coating

Table 3 Elemental wt.\% and oxide (mol.\%) of the starting P-40 glass powder and top of the surfaces of both coatings (50 kW and $75 \mathrm{~kW})$ measured via EDX

\begin{tabular}{lcccc}
\hline Element/oxide & $\begin{array}{c}\text { Elemental wt.\%/oxide } \\
\left(\begin{array}{c}\text { mol.\% }) \text { based on } \\
\text { P-40 formula }\end{array}\right.\end{array}$ & $\begin{array}{c}\text { P-40 powder elemental } \\
\text { wt.\%/oxide, mol.\% }\end{array}$ & $\begin{array}{c}\text { P-40 coating deposited } \\
\text { at 50 kW elemental } \\
\text { wt.\%/ oxide, mol.\% }\end{array}$ & $\begin{array}{c}\text { P-40 coating deposited } \\
\text { at } 75 \mathrm{~kW} \text { elemental } \\
\text { wt.\%/ oxide, mol.\% }\end{array}$ \\
\hline${\mathrm{P} / \mathrm{P}_{2} \mathrm{O}_{5}}$ & $28.00 / 40.00$ & $26.0 \pm 0.0 / 36 \pm 1$ & $24 \pm 0 / 29 \pm 1$ & $22 \pm 0 / 27 \pm 0$ \\
$\mathrm{Na} / \mathrm{Na}_{2} \mathrm{O}$ & $10.36 / 20.00$ & $12.5 \pm 0.0 / 22 \pm 0$ & $7 \pm 0 / 11 \pm 0$ & $5 \pm 1 / 8 \pm 1$ \\
$\mathrm{Ca} / \mathrm{CaO}$ & $7.30 / 16.00$ & $6.2 \pm 0.0 / 13 \pm 0$ & $11 \pm 0 / 22 \pm 1$ & $13 \pm 1 / 24 \pm 2$ \\
$\mathrm{Mg} / \mathrm{MgO}$ & $5.00 / 24.00$ & $8.2 \pm 0.0 / 28 \pm 1$ & $11 \pm 0 / 36 \pm 1$ & $12 \pm 1 / 39 \pm 1$ \\
\hline
\end{tabular}




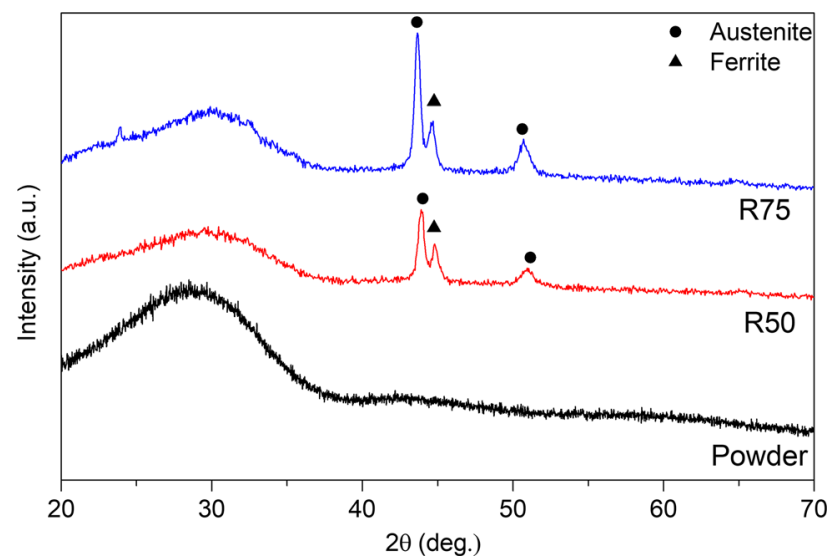

Fig. 5 XRD diffractograms of P-40 glass powders and coatings deposited at 50 and $75 \mathrm{~kW}$ flame power

between coating and substrate from the $8.2 \mathrm{wt} . \%$ present in the starting powder and remained at this value to the top of the coating. Some $\mathrm{Fe}$ and $\mathrm{Cr}$ were observed near the coating-substrate interface, which originated from the metal substrate used.

For the $75 \mathrm{~kW}$ P-40 glass coating, the same trend as for the $50 \mathrm{~kW}$ coating was observed. The composition was nearly the same along the cross section of the coating. However, some compositional variations relative to the starting material were observed. For example, $22.6 \mathrm{wt} . \%$ of $\mathrm{P}$ was observed at the coating-substrate interface, which increased to approximately $25 \mathrm{wt} \%$ at the top of the coating. Reduction in Na content was slightly more, which had reduced to $3.53 \mathrm{wt} . \%$ at the interface from the starting $12.5 \mathrm{wt} . \%$ (in the powder) and remained at this value till the top of the coating. 12 wt. $\%$ Ca was observed along the cross section of the coating. However, Ca content was less in the starting powder (6.2 wt.\%) before spray. Similarly, $\mathrm{Mg}$ wt.\% was observed to be increased to $11.74 \mathrm{wt} . \%$ along the coating cross section till the top of the coating from 8.2 wt.\% which was present in the powder.

Moreover, it can be seen (Table 3) that post-thermal spraying the $\mathrm{P}_{2} \mathrm{O}_{5}$ content of the starting glass powder decreased significantly from $36 \mathrm{~mol} . \%$ to $29 \mathrm{~mol} . \%$ (for the $50 \mathrm{~kW}$ coating) and $27 \mathrm{~mol} \%$ (for the $75 \mathrm{~kW}$ coating) as analyzed via EDX at the top surfaces of the coatings.

The amorphous nature of the P-40 glass did not seem to have changed and remained amorphous after thermal spraying at both flame powers, as shown by the XRD analysis in Fig. 5. The broad diffraction halos centered at $2 \theta \approx 30^{\circ}$ were identified in the starting powder and in both coatings produced. The only crystalline peaks visible were from the substrate confirmed to be austenite (PDF card no. 00-023-0298) and ferrite (PDF card no. 00-006-0696).

Raman spectroscopy analysis of the starting P-40 powder and the produced coatings are given in Fig. 6. For the

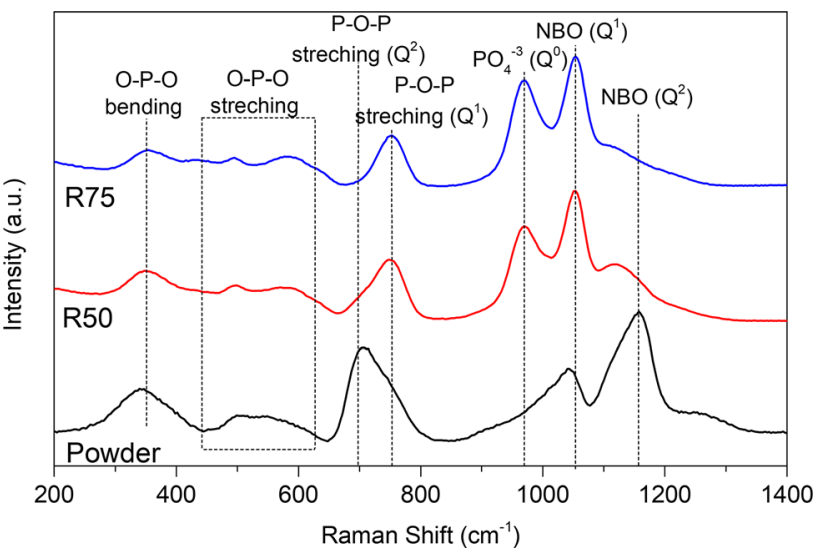

Fig. 6 Raman spectra of P-40 phosphate glass powder and coatings deposited at 50 and $75 \mathrm{~kW}$ flame power

P-40 powder, the peak at $351 \mathrm{~cm}^{-1}$ was related to bending vibrations of the O-P-O bonds associated with $\mathrm{Q}^{2}$ tetrahedral units (Ref 26). The low intensity peaks in the range of $470-620 \mathrm{~cm}^{-1}$ were suggested to be due to in-chain O-P-O stretching vibrations (Ref 26-28). The Raman peaks at $670-790 \mathrm{~cm}^{-1}$ were associated with the P-O-P symmetric stretching of the bridging oxygen in $\mathrm{Q}^{2}$ and $\mathrm{Q}^{1}$ units, respectively (Ref 29). In the previous study, it has been shown that P-40 formulation contained $50 \% \mathrm{Q}^{2}$ and $\mathrm{Q}^{1}$ units (Ref 30). The peak at $1040 \mathrm{~cm}^{-1}$ was related to symmetric stretching of $\mathrm{PO}_{2}$ non-bridging oxygen in $\mathrm{Q}^{1}$ unit (Ref 30), whereas the peak at $1160 \mathrm{~cm}^{-1}$ was associated to the symmetric stretching modes O-P-O nonbridging oxygen in $\mathrm{Q}^{2}$ phosphate units (Ref 29).

Post-thermal spraying, analysis of the P-40 glass coating at flame power 50 and $75 \mathrm{~kW}$ revealed that the peak at 670 $\mathrm{cm}^{-1}$ (which had been assigned to P-O-P symmetric stretching of the bridging oxygen in $\mathrm{Q}^{2}$ units) had disappeared, while the peak at $790 \mathrm{~cm}^{-1}$ had appeared for both coatings. A new peak was also observed at $960 \mathrm{~cm}^{-1}$ for both the 50 and $75 \mathrm{~kW}$ coatings which was associated with the symmetric stretching of orthophosphate group $\left(\mathrm{PO}_{4}{ }^{-3}\right)$ in $\mathrm{Q}^{0}$ unit $(\operatorname{Ref} 2,28)$. The intensity of the band at 1046 $\mathrm{cm}^{-1}$ (associated with $\mathrm{Q}^{1}$ unit) also increased for both coatings, while the peak intensity at $1160 \mathrm{~cm}^{-1}$ (associated with $\mathrm{Q}^{2}$ unit) decreased for the $50 \mathrm{~kW}$ coating and appeared as a shoulder in the Raman spectrum of the 75 kW coating (see Fig. 6).

\section{Ion Release Profiles}

Ion release profiles for the coatings were investigated using ICP-MS for the measurement of $\mathrm{Na}^{+}, \mathrm{Mg}^{2+}, \mathrm{Ca}^{2+}$, and total $\mathrm{P}$ ions in Milli-Q water. The cumulative ion release profiles of both coatings are presented in Fig. 7. The ion release rates were calculated as the slope from the linear interpolation of the values and are given in Table 4. 
Fig. $7 \mathrm{Na}^{+}, \mathrm{Mg}^{2+}, \mathrm{P}^{5+}$, and $\mathrm{Ca}^{2+}$ ion release profile for $\mathrm{P}-40$ coatings (a) deposited at $50 \mathrm{~kW}$ and (b) $75 \mathrm{~kW}$
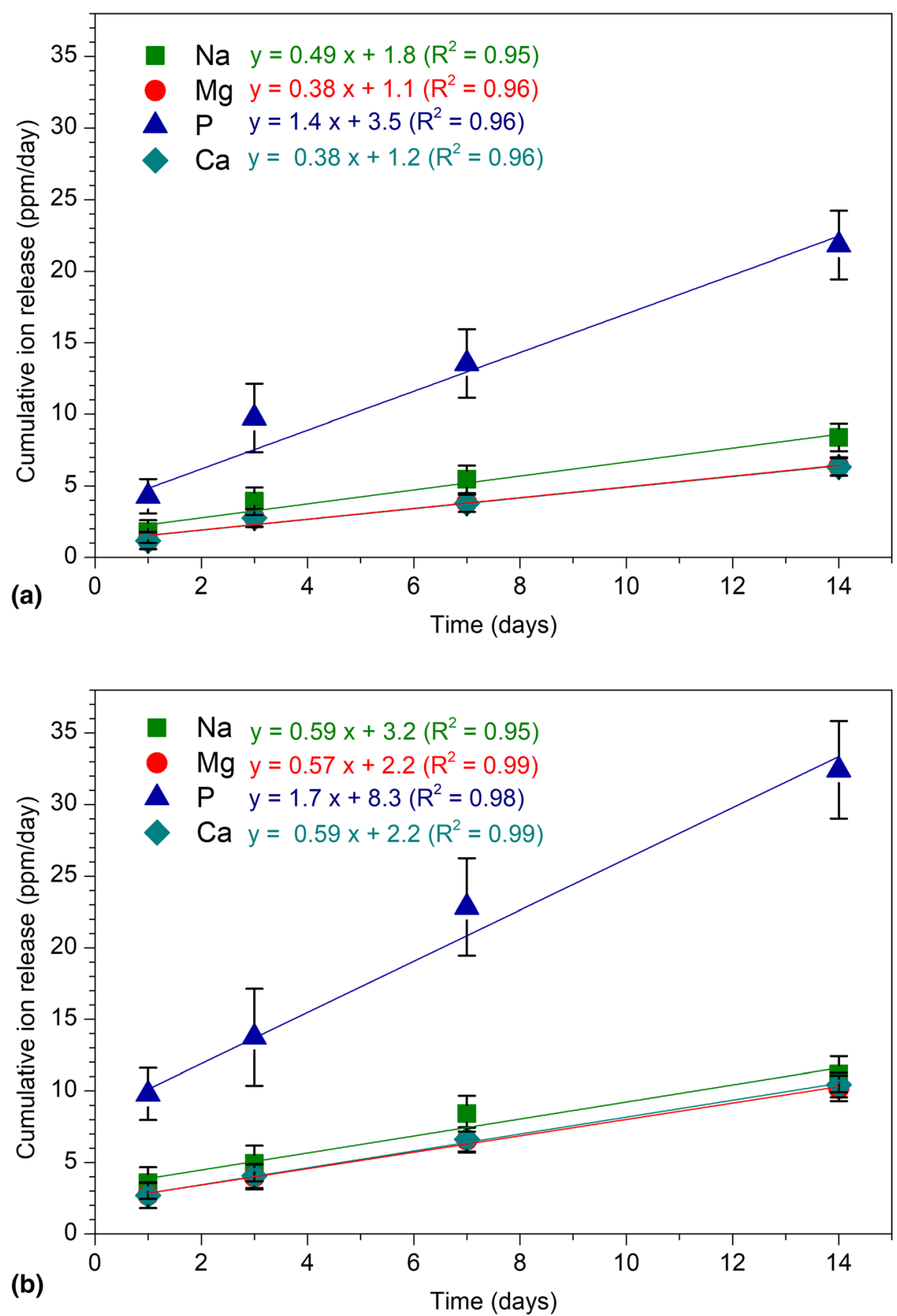

Table 4 Ion release rates (ppm/day) of P-40 coatings deposited at 50 and $75 \mathrm{~kW}$ in Milli-Q water, where number of samples $(n)=3$

\begin{tabular}{lcccc}
\hline P-40 coatings & Na release rate, ppm/day & Mg release rate, ppm/day & P release rate, ppm/day & Ca release rate, ppm/day \\
\hline $50 \mathrm{~kW}$ & $0.49 \pm 0.06$ & $0.38 \pm 0.04$ & $1.4 \pm 0.1$ & $0.38 \pm 0.04$ \\
$75 \mathrm{~kW}$ & $0.59 \pm 0.08$ & $0.57 \pm 0.02$ & $1.7 \pm 0.1$ & $0.59 \pm 0.02$ \\
\hline
\end{tabular}

For the $50 \mathrm{~kW}$ coating, the highest ion release was that of total $\mathrm{P}$ ions with the release rate of $1.4 \pm 0.1 \mathrm{ppm} /$ day, while the other ions such as $\mathrm{Na}^{+}, \mathrm{Ca}^{2+}$ and $\mathrm{Mg}^{2+}$ were released in similar amounts with the release rate of $0.38 \pm$ $0.04 \mathrm{ppm} /$ day for $\mathrm{Na}^{+}$and a rate of $0.49 \pm 0.06 \mathrm{ppm} /$ day for $\mathrm{Ca}^{2+}$ and $\mathrm{Mg}^{2+}$ (while $\mathrm{R}^{2}$ values for ions of $\mathrm{P}, \mathrm{Ca}, \mathrm{Na}$ 
and $\mathrm{Mg}$ were $0.95,0.98,0.99$ and 0.97$)$. Similar to the 50 $\mathrm{kW}$, the $75 \mathrm{~kW}$ coating also revealed total $\mathrm{P}$ ion released at the highest rate $(1.7 \pm 0.1 \mathrm{ppm} /$ day $)$ in comparison to other ions analyzed $\left(\mathrm{Na}^{+}, \mathrm{Ca}^{2+}\right.$ and $\left.\mathrm{Mg}^{2+}\right)$ which were released at $0.57 \pm 0.02 \mathrm{ppm} /$ day for $\mathrm{Mg}^{2+}$ and the same rate of 0.59 $\pm 0.08 \mathrm{ppm} /$ day and $0.59 \pm 0.02 \mathrm{ppm} /$ day for $\mathrm{Na}^{+}$and $\mathrm{Ca}^{2+}$, respectively (while $\mathrm{R}^{2}$ values for ions of $\mathrm{P}, \mathrm{Ca}, \mathrm{Na}$ and $\mathrm{Mg}$ were $0.982,0.996,0.950$ and 0.995$)$. It can also be seen that the overall ion release rates were higher for 75 $\mathrm{kW}$ coating than for the $50 \mathrm{~kW}$ coating.

\section{Degradation Studies}

Degradation profiles of the P-40 coatings deposited at 50 and $75 \mathrm{~kW}$ are shown in Fig. 8. The degradation rates revealed linear mass loss profiles for both coatings in Milli$Q$ water and PBS.

Degradation rate for the coatings was higher in MQ water compared to those in the PBS (see Fig. 8 and Table 5). The highest degradation rate of $1 \times 10^{-4} \mathrm{mg} /$ $\mathrm{mm}^{2}$. day was observed for the $75 \mathrm{~kW}$ coating in MQ water. The lowest degradation rate $\left(1 \times 10^{-5} \mathrm{mg} / \mathrm{mm}^{2}\right.$.day $)$ was observed for $50 \mathrm{~kW}$ in PBS, while this coating was degraded 5 times higher in Milli-Q water at the rate of $5 \times 10^{-5} \mathrm{mg} / \mathrm{mm}^{2} \cdot$ day.

\section{Discussion}

\section{Microstructure Formation in P-40 Coatings}

SHVOF thermal spraying at $50 \mathrm{~kW}$ and at $75 \mathrm{~kW}$ flame power resulted in globules on the surface of the coatings (see Fig. 2). In our previous work, it was observed that spraying of the silicate based bioactive glass (45S5) at 75 $\mathrm{kW}$ also resulted in globules on the surface of the coating (Ref 22), which were attributed to the formation of large agglomerates inside the combustion chamber during spray and subsequent deposition onto the substrate. A flame power of $75 \mathrm{~kW}$ had sufficient energy to melt these large agglomerates, resulting in homogeneous globules with a smooth surface (Ref 31 ). However, P-40 glass coating at 50 $\mathrm{kW}$ had the same globules on the surface of the coating, which means that the $50 \mathrm{~kW}$ flame power had enough heat energy for this glass to generate a similar surface topography to the $45 \mathrm{~S} 5$ coating deposited at $75 \mathrm{~kW}$ coating. This could be due to the low glass transition $\left(448 \pm 1{ }^{\circ} \mathrm{C}\right)$ and melting $\left(764 \pm 1{ }^{\circ} \mathrm{C}\right.$ ) temperature of the P-40 glass (Ref 11 ) in comparison to $45 \mathrm{~S} 5$ bioactive glass for which glass transition temperature is $520^{\circ} \mathrm{C}$ (Ref 32) and melting temperature is $1217^{\circ} \mathrm{C}$ ( $\operatorname{Ref} 33$ ). In globule-free areas, individual splats were not seen in both coatings, as a result of better melting of the material at both flame powers $(50$ and $75 \mathrm{~kW}$ ) due to the lower melting temperature of PBG.

Both P-40 glass coatings were dense and presented low porosity (Fig. 2), and this was attributed to the higher heat transfer at both flame powers, causing better melting of the $\mathrm{P}-40$ particles and leading to denser coatings in comparison to the Bioglass ${ }^{\circledR}$ coatings studied in our previous work (Ref 22, 25). However, the $75 \mathrm{~kW}$ coating was two thirds the thickness of the $50 \mathrm{~kW}$ coating which may have been due to the fact that the high flame power of $75 \mathrm{~kW}$ caused the material to evaporate (due to lower melting temperature of the PBGs (Ref 25), resulting in a thinner coating (Ref 22, 34).

EDX analysis along the cross section of the coatings (Fig. 4) showed that the P-40 composition with respect to the initial bulk formulation had been slightly altered due to the thermal spraying process, thereby imparting a new thermal prehistory on the samples produced. These variations in composition were observed from EDX area scan at the top surface of the coatings. As in Table 3, it can be seen that thermal spray caused reductions in contents of $\mathrm{P}$ and $\mathrm{Na}$ while spraying at 50 and $75 \mathrm{~kW}$. This might be due to the direct volatilization of $\mathrm{P}_{2} \mathrm{O}_{5}$ at high temperature (Ref 34). Reduction in the wt.\% of $\mathrm{Na}_{2} \mathrm{O}$ is attributed to its volatile nature ( $\mathrm{Ref} 35$ ). Loss of $\mathrm{Na}_{2} \mathrm{O}$ from the glass melt is due to the heterogeneous chemical reaction between $\mathrm{Na}_{2} \mathrm{O}$ and water vapors present in the combustion chamber resulting in $\mathrm{NaOH}$ (Ref 36 ). A decrease in the content of $\mathrm{Na}_{2} \mathrm{O}$ was followed by an increase in $\mathrm{CaO}$ content (Ref 36).

The structure of the initial P-40 glass was altered due to the thermal spray process as shown by the Raman analysis (Fig. 6), which showed that the Raman spectra of the coatings were different from the Raman spectrum of the $\mathrm{P}-40$ powder. A new peak was found at $960 \mathrm{~cm}^{-1}$ in the Raman spectra of coatings which was not present in the starting powder spectrum. In the literature, this band was associated with the symmetric stretching of orthophosphate groups $\left(\mathrm{PO}_{4}{ }^{-3}\right)(\operatorname{Ref} 28,29,37)$, which suggested that the P-40 glass had depolymerized forming $\mathrm{Q}^{\circ}$ units (Ref 26). Higher intensity of the peak at $1046 \mathrm{~cm}^{-1}$ in coatings spectra compared to $\mathrm{P} 40$ powder indicated a higher concentration of $\mathrm{Q}^{1}$ units (Ref 26). Moreover, the intensity of the peak at $1160 \mathrm{~cm}^{-1}$ decreased in the spectra of the coatings, and the decreased intensity of this peak in the coating spectra could be due to the reduction in the concentration of $Q^{2}$ units ( $\left.\operatorname{Ref} 26,29\right)$. Finally, the evolution of the peak at $670-790 \mathrm{~cm}^{-1}$ as at $750 \mathrm{~cm}^{-1}$ indicated a reduction in the chain length. It can be concluded from the Raman spectra that the P-40 glass structure changed as a reduction in the concentration of $\mathrm{Q}^{2}$ units, increased in $\mathrm{Q}^{1}$ units and the potential formation of $\mathrm{Q}^{\circ}$ units. In Raman analysis, the observation of orthophosphate $\left(\mathrm{PO}_{4}{ }^{-3}\right)$ peak/ 
Fig. 8 (a) Degradation of P-40 coating deposited at $50 \mathrm{~kW}$ and (b) $75 \mathrm{~kW}$ in PBS and MQ water
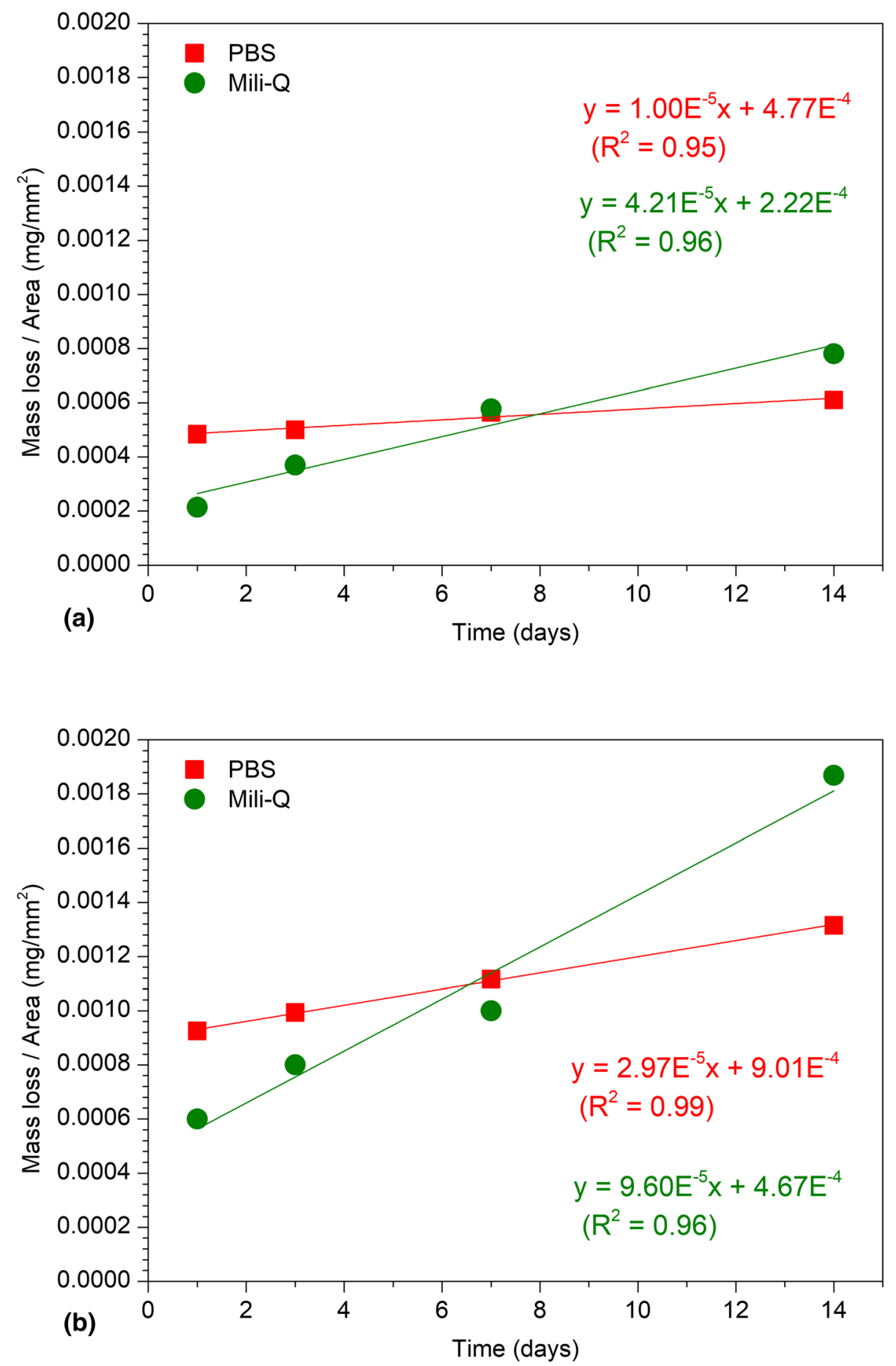

Table 5 Degradation rate of P-40 coatings deposited at 50 and $75 \mathrm{~kW}$ in PBS and MQ

\begin{tabular}{lcc}
\hline P-40 coatings & Degradation rate in PBS, $\times 10^{-5} \mathrm{mg} / \mathrm{mm}^{2}$ day & Degradation rate in $\mathrm{MQ}$ water, $\times 10^{-5} \mathrm{mg} / \mathrm{mm}^{2}$ day \\
\hline $50 \mathrm{~kW}$ & 1 & 4 \\
$75 \mathrm{~kW}$ & 3 & 10 \\
\hline
\end{tabular}


$\mathrm{Q}^{0}$ species in both coatings could be attributed to the reduction of $\mathrm{P}_{2} \mathrm{O}_{5}$ content (from $36 \mathrm{~mol} \%$ for glass powder to $27-29 \mathrm{~mol} . \%$ for coatings) post-thermal spray which is confirmed via EDX. In literature, it has been reported that the $\mathrm{Q}^{0}$ species was observed for the phosphate glasses, which contained $\mathrm{P}_{2} \mathrm{O}_{5}$ below 35 mol.\% (Ref 38).

This structural analysis warrants further investigation, via NMR characterization. However, the challenges are ensuring that sufficient powder samples can be obtained from the coatings deposited for accurate analysis.

\section{Ion Release Profiles and Degradation Studies}

From the ion release studies conducted (Table 4), it can be seen that, for both coatings, ion release rates ranked $\mathrm{P}>\mathrm{Na}$ $>\mathrm{Mg}>\mathrm{Ca}$. P-40 coatings suffered a structural change during spraying and present a higher ratio of $\mathrm{Q}^{1}$ and $\mathrm{Q}^{0}$ species than the initial glass, as observed from Raman analysis, and these changes in the glass structure had an effect on the glass solubility. In PBGs, $\mathrm{Q}^{2}$ species are more soluble than species with a lower degree of polymerization (i.e., $\mathrm{Q}^{1}$ and $\mathrm{Q}^{0}$ ), so the $\mathrm{P}-40$ coatings with a higher ratio of depolymerized species $\left(\mathrm{Q}^{1}\right.$ and $\mathrm{Q}^{0}$ species) will present reduced ion release profiles than the initial glass. Ion release study of P-40 bulk glass has been conducted by Islam et al. (Ref 11), who reported ion release rates of 0.8 $\mathrm{ppm} /$ day for $\mathrm{Mg}, 0.9 \mathrm{ppm} / \mathrm{day}$ for $\mathrm{Ca}$ and $1.55 \mathrm{ppm} /$ day for $\mathrm{Na}$ ions, and these values were significantly higher than the ones obtained for the thermal sprayed P-40 coatings of this study, indicating that the produced coatings were more resistant to hydrolytic attack, due to the structural changes induced in the glass during spraying, as proved by Raman analysis (Fig. 6).

The ion release rates were also influenced by the spray conditions, and the intensity of the bands associated with $\mathrm{Q}^{1}$ and $\mathrm{Q}^{0}$ species was very similar for both spray conditions. However, a higher ratio of depolymerized species was present in the coatings deposited at $75 \mathrm{~kW}$, whereas a band associated with $Q^{2}$ units $\left(1160 \mathrm{~cm}^{-1}\right)$ was absent in the $75 \mathrm{~kW}$ coating while was present in the $50 \mathrm{~kW}$ coating (see Fig. 6). Therefore, according to the glass chemistry, higher dissolution rates should be expected on the $50 \mathrm{~kW}$ coating. However, the coating deposited at $75 \mathrm{~kW}$ presented higher release rates than the coating deposited at 50 $\mathrm{kW}$. This could be due to the rougher surface of the $75 \mathrm{~kW}$ coating, which involves a larger surface area in contact with the liquid, contributing to an increased ion leaching in comparison to the $50 \mathrm{~kW}$ coating (Ref 25). This could indicate that small changes in the glass structure of the coating had a limited effect on the ion release rates.

The degradation rates of the coatings followed the same behavior as the ion release profiles. In Milli-Q water and PBS, both coatings were more stable and presented lower degradation rates than the PBGs thin films (produced via magnetron sputtering) reported in the literature (Ref 39), probably due to the presence of a higher rate of depolymerized species. Also, the enrichment of $\mathrm{MgO}$ in the coating composition from the initial glass, which is due to the volatilization of labile elements during spraying, has an important role because PBGs with higher $\mathrm{MgO}$ content tend to present lower degradation rates (Ref 11). The P-40 coating deposited at $75 \mathrm{~kW}$ showed higher degradation than the coating deposited at $50 \mathrm{~kW}$ (Fig. 8, Table 5), and this could be attributed to the higher surface roughness of the $75 \mathrm{~kW}$ coating.

Overall, the PBG thermal sprayed coatings showed lower degradation and ion release rates in comparison to the starting glass powder and to those reported in the literature for bulk PBG and PBG thin films. This behavior of the PBG thermal sprayed coatings could be attributed to the change in the structure of the glass as revealed via Raman analysis (although further analysis is still required).

\section{Conclusion}

The SHVOF thermal spray technique was used to deposit P-40 PBG on to stainless steel substrate at two flame powers of 50 and $75 \mathrm{~kW}$. Surface topography of both coatings was very similar, showing globules on the top surface of the coatings. However, ion release profiles and degradation rates of both coatings were different, which might be due to the difference surface roughness of the coatings. Both coatings were amorphous as shown by XRD analysis; however, the structure of the coatings was different from that of the starting powder as revealed by Raman analysis with the reduction in the concentration of $\mathrm{Q}^{2}$ specie, increased of $\mathrm{Q}^{1}$ specie and the formation of $\mathrm{Q}^{0}$ specie in coatings.

$75 \mathrm{~kW}$ coating showed more mass loss and ion leaching in comparison to $50 \mathrm{~kW}$ coating, which could be due to the rougher surface of the $75 \mathrm{~kW}$ coating. However, comparing these results with those reported in the literature for thin films of P-40 glass and bulk P-40 glass, both coatings showed lower degradation and ions release rates.

Acknowledgments This work was supported by the Engineering and Physical Sciences Research Council [EP/N50970X/1). Saira Bano acknowledges a fully funded Faculty of Engineering Research Excellence $\mathrm{PhD}$ scholarship for international students by University of Nottingham, UK (Sponsor License Number RFDX42DB2, Scholarship Ref Number: 16453). Saira Bano is a lecturer at the University of Engineering and Technology Peshawar, Pakistan. We acknowledge support from Mr. John Kirk for thermal spray experiments. We gratefully acknowledge technical support from Scott Young in ion leaching tests, as well as the Nanoscale and Microscale Research Centre (NMRC) at University of Nottingham for access to the SEM and Raman spectroscopy facilities. 
Open Access This article is licensed under a Creative Commons Attribution 4.0 International License, which permits use, sharing, adaptation, distribution and reproduction in any medium or format, as long as you give appropriate credit to the original author(s) and the source, provide a link to the Creative Commons licence, and indicate if changes were made. The images or other third party material in this article are included in the article's Creative Commons licence, unless indicated otherwise in a credit line to the material. If material is not included in the article's Creative Commons licence and your intended use is not permitted by statutory regulation or exceeds the permitted use, you will need to obtain permission directly from the copyright holder. To view a copy of this licence, visit http://creativecommons. org/licenses/by/4.0/.

\section{References}

1. R.A. Velapoldi, L. Boehm and M.I. Shalom, Phosphate Glasses, 1971, 76, p 1-4.

2. I. Ahmed, H. Ren and J. Booth, Developing Unique Geometries of Phosphate-Based Glasses and their Prospective Biomedical Applications, Johnson Matthey Technol. Rev., 2018, 63(1), p 34-42. https://doi.org/10.1595/205651319x15426460058863

3. I. Ahmed, M. Lewis, I. Olsen and J.C. Knowles, Phosphate Glasses for Tissue Engineering: Part 1. Processing and Characterisation of a Ternary-Based P2O5-CaO-Na $2 \mathrm{O}$ Glass System, Biomaterials, 2004, 25(3), p 491-499. https://doi.org/10.1016/ S0142-9612(03)00546-5

4. E.A. Abou Neel et al., Doping of a High Calcium Oxide Metaphosphate Glass with Titanium Dioxide, J. Non. Cryst. Solids, 2009, 355(16-17), p 991-1000. https://doi.org/10.1016/j. jnoncrysol.2009.04.016

5. D.S. Brauer, M.N. Anjum, M. Mneimne, R.M. Wilson, H. Doweidar and R.G. Hill, Fluoride-Containing Bioactive GlassCeramics, J. Non. Cryst. Solids, 2012, 358(12-13), p 1438-1442. https://doi.org/10.1016/j.jnoncrysol.2012.03.014

6. E.A. Abou Neel et al., Structure and Properties of StrontiumDoped Phosphate-Based Glasses, J. R. Soc. Interface, 2009, 6(34), p 435-446. https://doi.org/10.1098/rsif.2008.0348

7. J.C.K. Ensanya Ali Abou Neel and W. Chrzanowski, Effect of Increasing Titanium Dioxide Content on Bulk and Surface Properties of Phosphate-Based Glasses, Acta Biomater., 2008, 4(3), p 523-534. https://doi.org/10.1016/j.biomaterials.2004.07. 024

8. I. Ahmed et al., The Structure and Properties of Silver-Doped Phosphate-Based Glasses, J. Mater. Sci., 2007, 42(23), p 9827-9835. https://doi.org/10.1007/s10853-007-2008-9

9. E.A. Abou Neel, W. Chrzanowski and J.C. Knowles, Effect of Increasing Titanium Dioxide Content on Bulk and Surface Properties of Phosphate-Based Glasses, Acta Biomater., 2008, 4(3), p 523-534. https://doi.org/10.1016/j.actbio.2007.11.007

10. I. Ahmed, C.A. Collins, M.P. Lewis, I. Olsen and J.C. Knowles, Processing, Characterisation and Biocompatibility of Iron-Phosphate Glass Fibres for Tissue Engineering, Biomaterials, 2004, 25(16), p 3223-3232. https://doi.org/10.1016/j.biomaterials.2003. 10.013

11. M.T. Islam, K.M.Z. Hossain, N. Sharmin, A.J. Parsons and I. Ahmed, Effect of Magnesium Content on Bioactivity of Near Invert Phosphate-Based Glasses, Int. J. Appl. Glas. Sci., 2017, 8(4), p 391-402. https://doi.org/10.1111/ijag.12320

12. M.T. Islam, R.M. Felfel, E.A. Abou Neel, D.M. Grant, I. Ahmed and K.M.Z. Hossain, Bioactive Calcium Phosphate-Based Glasses and Ceramics and Their Biomedical Applications: A Review, J. Tissue Eng., 2017 https://doi.org/10.1177/2041731417719170
13. H. Gao, T. Tan and D. Wang, Dissolution Mechanism and Release Kinetics of Phosphate Controlled Release Glasses in Aqueous Medium, J. Control. Release, 2004, 96(1), p 29-36. https://doi.org/10.1016/j.jconrel.2003.12.031

14. B.C. Bunker, G.W. Arnold and J.A. Wilder, Phosphate Glass Dissolution in Aqueous Solutionsitle, J. Non. Cryst. Solids, 2021, 64(3), p 291-316.

15. B.W. Stuart, M. Gimeno-Fabra, J. Segal, I. Ahmed and D.M. Grant, Degradation and Characterization of Resorbable Phosphate-Based Glass Thin-Film Coatings Applied by Radio-Frequency Magnetron Sputtering, ACS Appl. Mater. Interfaces, 2015, 7(49), p 27362-27372. https://doi.org/10.1021/acsami. $5 b 08957$

16. E.A. Abou Neel et al., Effect of Iron on the Surface, Degradation and Ion Release Properties of Phosphate-Based Glass Fibres, Acta Biomater., 2005, 1(5), p 553-563. https://doi.org/10.1016/j.act bio.2005.05.001

17. M.T. Islam, L. Macri-Pellizzeri, K.M.Z. Hossain, V. Sottile and I. Ahmed, "Effect of Varying the Mg with Ca Content in Highly Porous Phosphate-Based Glass Microspheres, Mater. Sci. Eng. C, 2021, 120, p 111668. https://doi.org/10.1016/j.msec.2020.111668

18. K.M.Z. Hossain et al., Porous Calcium Phosphate Glass Microspheres for Orthobiologic Applications, Acta Biomater., 2018, 72, p 396-406. https://doi.org/10.1016/j.actbio.2018.03.040

19. B.W. Stuart, J.J. Titman, M. Gimeno-Fabra, I. Ahmed and D.M. Grant, Insights into Structural Characterisation and Thermal Properties of Compositionally Equivalent Vapour-Condensed and Melt-Quenched Glasses, Mater. Des., 2016, 111, p 174-184. https://doi.org/10.1016/j.matdes.2016.08.063

20. B. Stuart, M. Gimeno-Fabra, J. Segal, I. Ahmed and D.M. Grant, Preferential Sputtering in Phosphate Glass Systems for the Processing of Bioactive Coatings, Thin Solid Films, 2015, 589, p 534-542. https://doi.org/10.1016/j.tsf.2015.05.072

21. P.J. Kelly and R.D. Arnell, Magnetron Sputtering: A Review of Recent Developments and Applications, Vacuum, 2000, 56(3), p 159-172. https://doi.org/10.1016/S0042-207X(99)00189-X

22. S. Bano, I. Ahmed, D.M. Grant, A. Nommeots-Nomm and T. Hussain, Effect of processing on microstructure, mechanical properties and dissolution behaviour in SBF of Bioglass (45S5) coatings deposited by Suspension High Velocity Oxy Fuel (SHVOF) thermal spray, Surf. Coat. Technol., 2019, 372(May), p 229-238. https://doi.org/10.1016/j.surfcoat.2019.05.038

23. G. Bolelli et al., Comparison between Suspension Plasma Sprayed and High Velocity Suspension Flame Sprayed bioactive coatings, Surf. Coat. Technol., 2015, 280, p 232-249. https://doi. org/10.1016/j.surfcoat.2015.08.039

24. J.W. Murray, A.S.M. Ang, Z. Pala, E.C. Shaw and T. Hussain, Suspension High Velocity Oxy-Fuel (SHVOF)-Sprayed Alumina Coatings: Microstructure, Nanoindentation and Wear, J. Therm. Spray Technol., 2016, 25(8), p 1700-1710. https://doi.org/10. 1007/s11666-016-0462-0

25. M. Bai, R. Khammas, L. Guan, J.W. Murray and T. Hussain, Suspension High Velocity Oxy-Fuel Spraying of a Rutile TiO2 Feedstock: Microstructure, Phase Evolution and Photocatalytic Behaviour, Ceram. Int., 2017, 43(17), p 15288-15295. https://doi. org/10.1016/j.ceramint.2017.08.068

26. B.W. Stuart, C.A. Grant, G.E. Stan, A.C. Popa, J.J. Titman and D.M. Grant, Gallium Incorporation into Phosphate Based Glasses: Bulk and Thin Film Properties, J. Mech. Behav. Biomed. Mater., 2018, 82(March), p 371-382. https://doi.org/10.1016/j. jmbbm.2018.03.041

27. J.E. Pemberton, L. Latifzadeh, J.P. Fletcher and S.H. Risbud, Raman Spectroscopy of Calcium Phosphate Glasses with Varying $\mathrm{CaO}$ Modifier Concentrations, Chem. Mater., 1991, 3(1), p 195-200. https://doi.org/10.1021/cm00013a039 
28. A.K. Yadav and P. Singh, A Review of the Structures of Oxide Glasses by Raman Spectroscopy, RSC $A d v$., 2015, 5(83), p 67583-67609. https://doi.org/10.1039/c5ra13043c

29. S. Kaoua, S. Krimi, A. El Jazouli, E.K. Hlil and D. de Waal, Preparation and Characterization of Phosphate Glasses Containing Titanium and Vanadium, J. Alloys Compd., 2007, 429(1-2), p 276-279. https://doi.org/10.1016/j.jallcom.2006.04.004

30. M.T. Islam et al., The Effect of $\mathrm{MgO} / \mathrm{TiO} 2$ on Structural and Crystallization Behavior of Near Invert Phosphate-Based Glasses. J, Biomed. Mater. Res. Part B Appl. Biomater., 2019, 3, p 1-13. https://doi.org/10.1002/jbm.b.34421

31. G. Bolelli, V. Cannillo, R. Gadow, A. Killinger, L. Lusvarghi and J. Rauch, Investigation of High-Velocity Suspension Flame Sprayed (HVSFS), Ceram. Silikaty, 2010, 54(1), p 1-7. https:// doi.org/10.1016/j.jeurceramsoc.2009.01.032

32. D. Groh, F. Döhler and D.S. Brauer, Bioactive Glasses with Improved Processing. Part 1. Thermal Properties, Ion Release and Apatite Formation, Acta Biomater., 2014, 10(10), p 4465-4473. https://doi.org/10.1016/j.actbio.2014.05.019

33. B. Pföss, M. Höner, M. Wirth, A. Bührig-Polaczek, H. Fischer and R. Conradt, Structuring of Bioactive Glass Surfaces at the Micrometer Scale by Direct Casting Intended to Influence Cell Response, Biomed. Glas., 2016, 2(1), p 63-71. https://doi.org/10. 1515/bglass-2016-0008

34. R.G.C. Beerkens, Modeling the Kinetics of Volatilization from Glass Melts, J. Am. Ceram. Soc., 2001, 84(9), p 1952-1960. https://doi.org/10.1111/j.1151-2916.2001.tb00942.x
35. D. M. Sanders, W. K. Haller, Effect of Water Vapor on Sodium Vaporization from Two Silica-Based Glasses, Am. Soc. Ceram., 1977, 60(3-4), p 138-141. https://doi.org/10.1111/j.1151-2916. 1977.tb15489.x

36. F. Pigeonneau, H. Kočárková and F. Rouyer, Stability of Vertical Films of Molten Glass Due to Evaporation, Colloids Surf. A Physicochem. Eng. Asp., 2012, 408, p 8-16. https://doi.org/10. 1016/j.colsurfa.2012.04.014

37. A. Kiani et al., Structural Characterization and Physical Properties of $\mathrm{P}_{2} \mathrm{O}_{5}-\mathrm{CaO}-\mathrm{Na}_{2} \mathrm{O}-\mathrm{TiO}_{2}$ Glasses by Fourier Transform Infrared, Raman and Solid-State Magic Angle Spinning Nuclear Magnetic Resonance Spectroscopies, Acta Biomater., 2012, 8(1), p 333-340. https://doi.org/10.1016/j.actbio.2011.08.025

38. T. Moeller, Phosphorus and its Compounds. Volume I: Chemistry. J. Am. Chem. Soc., 1959, 81(11), p 2916. https://doi.org/10. 1021/ja01520a086

39. B.W. Stuart, M. Gimeno-Fabra, J. Segal, I. Ahmed and D.M. Grant, Mechanical, Structural and Dissolution Properties of Heat Treated Thin-Film Phosphate Based Glasses, Appl. Surf. Sci., 2017, 416, p 605-617. https://doi.org/10.1016/j.apsusc.2017.04. 110

Publisher's Note Springer Nature remains neutral with regard to jurisdictional claims in published maps and institutional affiliations. 